\title{
Estrogen Receptor Functions and Pathways at the Vascular Immune Interface
}

\author{
Aida Dama ${ }^{1,+}$, Chiara Baggio ${ }^{2,+}$, Carlotta Boscaro ${ }^{2}$, Mattia Albiero ${ }^{1,3}$ and Andrea Cignarella $1, *$ (D) \\ 1 Department of Medicine, University of Padova, 35128 Padova, Italy; aida.dama@unipd.it (A.D.); \\ mattia.albiero@gmail.com (M.A.) \\ 2 Department of Pharmaceutical and Pharmacological Sciences, University of Padova, 35128 Padova, Italy; \\ chiara.baggio.5@phd.unipd.it (C.B.); carlotta.boscaro@unipd.it (C.B.) \\ 3 Venetian Institute of Molecular Medicine, 35129 Padova, Italy \\ * Correspondence: andrea.cignarella@unipd.it; Tel.: +39-049-821-4272 \\ + These Authors contributed equally to this work.
}

Citation: Dama, A.; Baggio, C.; Boscaro, C.; Albiero, M.; Cignarella, A. Estrogen Receptor Functions and Pathways at the Vascular Immune Interface. Int. J. Mol. Sci. 2021, 22, 4254. https://doi.org/10.3390/ ijms 22084254

Academic Editor: Tea Lanišnik Rižner

Received: 4 March 2021

Accepted: 14 April 2021

Published: 20 April 2021

Publisher's Note: MDPI stays neutral with regard to jurisdictional claims in published maps and institutional affiliations.

Copyright: (c) 2021 by the authors. Licensee MDPI, Basel, Switzerland. This article is an open access article distributed under the terms and conditions of the Creative Commons Attribution (CC BY) license (https:/ / creativecommons.org/licenses/by/ $4.0 /)$.

\begin{abstract}
Estrogen receptor (ER) activity mediates multiple physiological processes in the cardiovascular system. ER $\alpha$ and ER $\beta$ are ligand-activated transcription factors of the nuclear hormone receptor superfamily, while the G protein-coupled estrogen receptor (GPER) mediates estrogenic signals by modulating non-nuclear second messengers, including activation of the MAP kinase signaling cascade. Membrane localizations of ERs are generally associated with rapid, non-genomic effects while nuclear localizations are associated with nuclear activities/transcriptional modulation of target genes. Gender dependence of endothelial biology, either through the action of sex hormones or sex chromosome-related factors, is becoming increasingly evident. Accordingly, cardiometabolic risk increases as women transition to menopause. Estrogen pathways control angiogenesis progression through complex mechanisms. The classic ERs have been acknowledged to function in mediating estrogen effects on glucose metabolism, but $17 \beta$-estradiol also rapidly promotes endothelial glycolysis by increasing glucose transporter 1 (GLUT1) and 6-phosphofructo-2-kinase/fructose-2,6biphosphatase 3 (PFKFB3) levels through GPER-dependent mechanisms. Estrogens alter monocyte and macrophage phenotype(s), and induce effects on other estrogen-responsive cell lineages (e.g., secretion of cytokines/chemokines/growth factors) that impact macrophage function. The pharmacological modulation of ERs for therapeutic purposes, however, is particularly challenging due to the lack of ER subtype selectivity of currently used agents. Identifying the determinants of biological responses to estrogenic agents at the vascular immune interface and developing targeted pharmacological interventions may result in novel improved therapeutic solutions.
\end{abstract}

Keywords: estrogens; estrogen receptors; gender differences; endothelium; monocytes; macrophages

\section{The Vascular Immune Interface}

Maintenance of vascular homeostasis is critical in both physiology and pathology, and the endothelium plays a significant role in vascular function [1]. Among other risk factors, low-density lipoprotein cholesterol (LDL-C) plays a central role in the development of endothelial dysfunction and atherosclerotic plaques. LDL-C, and probably other lipoproteins such as the small dense LDL particles and lipoprotein (a), traverse endothelial cells and undergo oxidative modification by reactive oxygen species. Once oxidized, these lipoproteins can promote atherosclerosis through several different mechanisms. First, oxidized lipoproteins facilitate monocyte recruitment. Second, oxidized lipoproteins may stimulate the expression of adhesion molecules of the vascular endothelium, promoting the adhesion of these monocytes to the vascular wall, one of the first steps in plaque development [2,3]. Third, these monocytes can then enter the vascular intima where they take up oxidized lipoproteins via scavenger receptors, converting them to foam cells. Finally, 
the oxidized lipoproteins can directly damage endothelial cells, further enhancing the rate of LDL penetration into the vessel [2,3].

Accumulation of inflammatory cells is a critical step in the development and progression of atherosclerotic lesions [4]. Monocytes are released from bone marrow into the circulatory system and they reach target tissues in response to injury, where they differentiate into mature macrophages. In the vessel wall, monocyte-derived macrophages are involved in the initiation of atherogenesis and formation of fatty streaks [5]. The focal attachment of monocytes to the endothelium and their subsequent transendothelial migration are important components for atherosclerotic lesion formation and progression $[4,5]$. Pro-inflammatory leukocytes are recruited to the site of atherosclerotic plaque development through interaction with several adhesion molecules expressed by endothelial cells. Through several mechanisms, monocytes perpetuate the inflammatory response to noxious stimuli, form foam cells and produce locally released cytokines (interleukin (IL)-6, TNF- $\alpha$ ), which are important for plaque formation [6]. Subsets of activated monocytes are also necessary for the initiation and modulation of the immune response, mainly through activation of nuclear factor kappa B (NF-kB)-related transcription, leading to the production and secretion of proinflammatory signaling mediators and cytokines $[7,8]$.

In summary, atherosclerosis can be considered as both a lipid metabolism disorder and a chronic inflammatory disease. Macrophages play a central role in atherogenesis through the accumulation of cholesterol and the production of inflammatory mediators and cytokines. This series of events occurs at the vascular immune interface, which represents a critical site for targeted pharmacological intervention [2,9].

\section{Cardiovascular Risk in Women}

Cardiometabolic risk increases with progressing age in both sexes and especially with menopausal transition in women. This increased risk coincides with the reproductive hormone loss that occurs as women transition to menopause. Women are protected from atherosclerosis until menopause, a finding attributed to the shielding effect of estrogens. $17 \beta$-estradiol (E2) is the major circulating estrogen in pre-menopausal females; several lines of evidence suggest that E2 has protective effects on the cardiovascular system, but the molecular mechanisms remain partially unknown [10,11]. Estrogens have been shown to slow down the development of atherosclerosis both in animal models and in humans [12]. By contrast, postmenopausal decline of estrogen production along with a variety of sex-specific risk factors is believed to be responsible for the increased incidence of cardiovascular disease in women following menopause $[13,14]$. Cardiovascular disorders are associated with endothelial dysfunction and the activation of the monocyte-macrophage system $[15,16]$. As discussed below, postmenopausal estrogen loss is also associated with impaired alternative activation in macrophages, which may contribute to the worsening of cardiovascular risk profile [17].

\section{Estrogen Receptors in the Cardiovascular System}

Estrogens exert both rapid and long-term actions through their binding with estrogen receptors (ERs). ERs are ligand-inducible transcription factors and are members of the nuclear hormone receptor superfamily. Several ERs have been identified: the nuclear subtypes, $\mathrm{ER} \alpha$ and $\mathrm{ER} \beta$, and the transmembrane G-protein-coupled receptor 30/G-protein estrogen receptor (GPER) [18]. ER $\alpha$ and ER $\beta$ mainly act as transcription factors responsible for many genomic effects, modulating gene expression by direct binding to DNA at specific estrogen response elements. Splice variants of the full-length ER $\alpha$ (ER $\alpha 66)$ including ER $\alpha 36$ and ER $\alpha 46$ have been identified in different cell types including human macrophages $[19,20]$ and appear to mediate rapid anti-inflammatory estrogen actions. There is evidence for ER $\beta$ splice variants in peripheral blood mononuclear cells (PBMC) [21] but their functional role has not been investigated. GPER is mainly involved in mediating rapid intracellular responses induced by E2 [22]. Membrane localizations of sex steroid receptors are generally 
associated with rapid, non-genomic effects, while intracellular localizations are associated with nuclear/transcriptional activities.

GPER is a newly discovered 7-pass transmembrane receptor that mediates many of the acute as well as chronic effects of E2. GPER mediates estrogenic signals by modulating nonnuclear second messengers, including activation of the mitogen-activated protein kinases (MAPK) signaling cascade [23]. Since its recognition as an estrogen receptor about 15 years ago, its roles in the cardiovascular system have been increasingly recognized. For instance, chronic in vivo GPER activation mimics the antihypertensive effects of estradiol [24]. GPER moderates many $\mathrm{Ca}^{2+}$-dependent activities that control cardiovascular pressor responses through a feed-forward loop in which GPER mediates the actions of E2 [25].

The functional role of ER subtypes has been investigated in vivo. For instance, experimental evidence indicates that targeted deletion of the Esr1 gene encoding for ER $\alpha$ results in several abnormalities, including tissue inflammation and insulin resistance [26]. Mice deficient in the Esr2 gene encoding for ER $\beta$ display increased systemic arterial blood pressure [27]. Increased vasoconstrictor tone has been observed in Gper-deficient mice [28]. We previously reported that rapid relaxion of precontracted arterial tissue is triggered by $E R \alpha$ - but not $E R \beta$-selective agonists [29]. However, dissection of specific estrogen signaling mechanisms is complicated by tissue specific estrogen regulation of transcription, membrane-delimited signaling that synergizes in mediating transcriptional changes and ligand-independent ER regulation of transcription [18]. In addition, cross talk between ERs has been reported for a number of endpoints. For example, E2-induced NO release is substantially reduced in the presence of the GPER-selective antagonist G36, suggesting that both ER $\alpha$ and GPER are involved in this process [30,31].

\section{Sex Differences and Estrogenic Pathways Regulate Endothelial Angiogenesis}

Gender dependence of endothelial biology, either through the action of sex hormones or sex chromosome-related factors, is becoming increasingly evident. Sex genotype and exposure to sexual hormones are relevant in angiogenesis outcomes. The hormonal microenvironment (i.e., estrogen exposure) and sex chromosomes modulate human umbilical vein endothelial cell (HUVEC) functional phenotypes and signaling involved in angiogenesis, demonstrating that the two features are important in conditioning the angiogenic response [32,33].

E2 stimulates endothelial cell proliferation in vitro [34] and in vivo [34-36], and inhibits spontaneous as well as TNF- $\alpha$-induced apoptosis [37,38]. Furthermore, E2 enhances adhesion of HUVECs to matrix proteins and increases cell migration, thus promoting angiogenesis [34,39]. The mechanisms responsible for the proangiogenic effect of E2 have been widely investigated and appear to be mediated at least in part by ER $\alpha$ activation [40]. In particular, E2 regulates actin remodeling and cell movement in HUVECs through the recruitment of focal adhesion kinase (FAK) [40]. Analysis of ER $\alpha$ knockout mice suggests that functional ERs are essential for the augmentation of basic fibroblast growth factor-induced angiogenesis by exogenous E2 [41].

Estrogenic pathways control angiogenesis through complex mechanisms [42]. An emerging regulatory mechanism is suggested by the observation that angiogenic signaling pathways converge onto metabolism [43]. The classic ERs have been acknowledged to function in mediating estrogen effects on glucose metabolism [44]. In addition, E2 rapidly promotes glycolysis in healthy endothelial cells by increasing glucose transporter 1 (GLUT1) and 6-phosphofructo-2-kinase/fructose-2,6-biphosphatase 3 (PFKFB3) levels. By interacting with GPER, E2 and the GPER agonist G1 enhance endothelial PFKFB3 stability and tubulogenesis by increasing deubiquitinase USP19 levels, thereby reducing PFKFB3 ubiquitination and proteasomal degradation. This involves a novel mechanism of estrogenic regulation of PFKFB3 mediated by GPER. E2 and G1 also increase endothelial GLUT1 protein expression via GPER through different mechanisms $[45,46]$. These findings suggest that ERs represent potential targets to afford selective modulation of endothelial function and angiogenesis. 
Angiogenesis is an in vivo phenomenon of multiple cell types: both endothelial and vascular smooth muscle cells can show the network formation in vitro. Targeting these pathways with ER selective agents might be a more rewarding strategy than current angiogenesis inhibitors, which induce remarkable cardiovascular side effects. Clinical aspects/complications risk that come with widespread angiogenesis blockade include stroke, pulmonary embolism and renal failure [47]. In view of the role of ER pathways at the crossroads of progression of certain cancer types and control of vascular function, ERs may represent promising targets for selective pharmacological modulation and personalized medicine.

\section{Estrogenic Pathways in the Monocyte-Macrophage System}

\subsection{Patterns of Estrogen Receptor Expression in Monocytes and Macrophages}

ER expression has been investigated in human monocytes and macrophages. These cells express all ERs. In primary monocyte-derived human macrophages and monocytic THP- 1 cells, transcripts for both ER $\alpha$ and ER $\beta$ were identified $[17,19,20,48]$. In primary human monocytes, ER $\alpha 36$ and GPER appear to be predominant [20]. Expression of ER $\alpha$ is greater than ER $\beta$ in monocytes, while macrophages express higher levels of $E R \alpha$ and lower levels of ER $\beta$ than monocytes. Full length ER $\alpha 66$ and the ER $\alpha 46$ splice variant are expressed in primary human monocytes and macrophages [19]. E2 induces ER $\alpha 46$ in macrophages, but has no effect on ER $\alpha$ expression in monocytes. Monocytes and macrophages also differ in the pattern of ER $\alpha 66$ and ER $\alpha 46$ expression: monocytes express equivalent levels of the two proteins, while in macrophages ER $\alpha 46$ is more highly expressed than ER $\alpha 66$ [19]. ER $\beta$ transcript and ER $\beta$ protein are not regulated by estrogen levels, suggesting a lack of autoregulation [49]. Many immune effects attributed to E2 in monocytes and macrophages are thought to be mediated through ER $\alpha$ and not ER $\beta[19,49,50]$. In fact, $\mathrm{ER} \alpha$ and ER $\beta$ target genes differ substantially. Campesi and colleagues [51] assessed the ability of lipopolysaccharide (LPS) to modulate in a sex-specific manner the expression and activation status of ER $\alpha$ and ER $\beta$ in blood monocyte-derived macrophages. In basal conditions, ER $\alpha$ and ER $\beta$ were significantly higher in female than in male monocytesderived macrophages. LPS upregulated ER $\alpha$ and its phosphorylation in both sexes, with a significantly higher effect observed in male macrophages, and downregulated ER $\beta$ level in female macrophages only [51]. Also, GPER is expressed in human monocytes and macrophages, where it mediates E2 anti-inflammatory actions [20].

\subsection{Estrogenic Pathways at the Vascular Immune Interface}

The role of monocytes and the effects of estrogen/ER pathways on these cells are especially relevant in atherogenesis. E2 induces a particularly robust modulatory effect on monocyte chemotaxis by reducing expression of monocyte chemotactic protein-1 (MCP-1, also known as CCL2), which results in decreased macrophage recruitment to the vessel wall [52]. E2 directly targets monocytes and inhibits monocyte adhesion under flow conditions [53]. Prior studies have shown that estrogens might indirectly affect monocyte adhesion by inhibiting adhesion molecule expression on the endothelial surface $[50,53,54]$.

As noted in Section 1 above, some LDL enters the arterial wall, where it undergoes modification (e.g., oxidation). Modified LDL induces expression of MCP-1, which recruits monocytes into the artery wall and stimulates their differentiation into macrophages. Macrophage uptake of the modified LDL results in formation of foam cells, the hallmark cell of atherosclerosis. Estrogens have a protective effect in the arterial wall through enhanced cellular cholesteryl ester hydrolysis and reduced LDL accumulation and degradation, processes dependent on foam cells (or lipid-loaded macrophages). Estrogens also inhibit oxidation of LDL by macrophages and can induce a direct antioxidative effect, thus reducing macrophage activation by oxidized LDL and preventing atherosclerosis progression [12,48-50,55]. Impaired ER $\alpha$ action in macrophages is causal for the development of aspects of the metabolic syndrome and increased atherosclerotic lesion formation in female 
mice [56], consistent with the notion that the atheroprotective effects of estradiol are largely mediated by ER $\alpha$ [57].

Estrogens may also affect expression of other members of the nuclear receptor superfamily with a relevant role in atherosclerosis. In particular, the liver $X$ receptor (LXR) is a sterol sensor that regulates intracellular cholesterol homeostasis and macrophage cholesterol efflux [58]. LXRs exert atheroprotective effects in the macrophage: in addition to regulating cholesterol metabolism, LXRs are also negative regulators of macrophage inflammatory gene responses [59]. Kramer et al. [48] reported that estrogen removal induces a significant decrease in the transcript levels of $L X R \alpha$. As discussed in Section 6 below, endogenous LXR ligands can also activate ERs. This suggests the occurrence of nuclear receptor cross-talk in macrophages [49,60], which warrants further investigation.

As described in more detail in Section 5.3 below, estrogens can alter macrophage phenotype(s) and function. However, beyond the direct effects on macrophages, there are effects of E2 on other estrogen-responsive cell lineages that can impact macrophage function (e.g., secretion of a variety of cytokines/chemokines/growth factors). For instance, monocyte/macrophage function is controlled by lymphocytes [61,62]; estrogenic modulation of these parameters has been found in humans and animals. Lymphocytes (as monocyte/macrophage function regulators) are also target for estrogens and express ERs, which may regulate, for example, IL-10 and IL-17 release [63]. Estrogen-mediated protection from inflammation also depends on the presence of B-cells [64]. Sex differences in $\mathrm{CD}^{+} \mathrm{T}$ cell and monocyte proportions are relevant and affected by ageing [65]. Of note, sex hormones act as epigenetic modifiers in innate immune cells [66]. It has been reported that the $\mathrm{CD} 4+/ \mathrm{CD} 8+$ ratio is associated with DNA methylation in postmenopausal women [67]. Therefore, ER action on epigenetic reprogramming plays a critical role in lymphocytes and may contribute to low-grade chronic inflammation as linked to menopause.

\subsection{Estrogens: Regulators of the Immune Function of the Monocyte-Macrophage System}

$\mathrm{ER} \alpha$ has anti-inflammatory actions that ER $\beta$ does not possess, consistent with the notion that overall $E R \alpha$ has greater protective effects than ER $\beta$. In addition to $E R \alpha$ and $\mathrm{ER} \beta$, estrogen can activate GPER, which is also found in macrophages. The potential role of GPER in immune cells and metabolic disease has been reviewed recently [68]. Macrophages are instructed by estrogens through receptor-mediated mechanisms of action to enable faster resolution of the inflammatory response and proper tissue remodeling. ER $\alpha$ null mutation in myeloid cells is an essential tool to dissect the direct versus indirect effects of E2 in macrophages [56], and reveal the contribution of ER $\alpha$ in maintaining key macrophage functions such as oxidative metabolism, phagocytosis, cholesterol uptake and phenotypic activation $[56,69,70]$.

Estrogens are known modulators of monocyte/macrophage functions; however, the underlying mechanism are still under investigation $[20,49,50]$. Several studies have shown that $\mathrm{E} 2$ acts as a regulator of the immune function of the monocyte-macrophage system, especially regarding the production of cytokines: their effects on the monocyte-macrophage system are primarily repressive [70-73]. Most of these effects are mediated by repression of gene expression for pro-inflammatory cytokines or other inflammatory mediators by ER-dependent or nongenomic pathways. The ER-dependent mechanisms mostly involve regulation of activity of the NF- $\mathrm{KB}$ pathway for transcriptional regulation of cytokines or other mediator genes. However, conflicting results have been reported from studies investigating the effects of estrogens on macrophage effector functions $[20,50,69]$. The estrogen-ER complex has been reported to inhibit binding of the NF- $\mathrm{kB}$ complex to regulatory areas of target genes, or to prevent nuclear translocation and transcriptional activation of the TNF- $\alpha$ gene [74]. IL-6 is one of the main cytokines involved in chronic inflammation-related monocyte functions. E2 is known to inhibit expression of TNF $\alpha$, IL-1 and IL-6. However, chronic exposure of murine macrophages to $\mathrm{E} 2$ in vivo increases production of pro-inflammatory cytokines [69]: in this regard, the literature is discordant with E2 enhancing or inhibiting secretion of TNF and IL-1 $\beta$ likely related to the duration of estrogen exposure and 
experimental design [72]. Long-term in vivo exposure to estrogens from endogenous or exogenous origin enhances the LPS-induced transcription of proinflammatory cytokines (IL-12, TNF- $\alpha$ ) by microglial cells through ER $\alpha$-dependent mechanisms [75]. In one study the anti-inflammatory effect of short-term in vitro exposure to E2 was reported in murine resident peritoneal macrophages [76], but chronic administration of E2 to ovariectomized female mice markedly increases the expression of numerous inflammatory cytokines and NO to LPS activation ex vivo [69]. In vitro pre-treatment with E2 of human macrophages inhibits the NF-KB signaling pathway and the production of TNF- $\alpha$ induced by LPS [20,76]. A significant increase in LPS-induced TNF- $\alpha$ release has been reported in ER $\alpha$-deficient macrophages, suggesting a prominent role of ER $\alpha$ in mediating the anti-inflammatory effects of estrogen. The deletion of ER $\alpha$ in hematopoietic cells in mice also causes an inability to induce the alternative phenotype in IL-4-stimulated macrophages as well as high levels of inflammation and insulin resistance, suggesting that ER $\alpha$ is involved in the control of inflammation [56,77]. Expression of the proinflammatory mediator IL-8/CXC-motif ligand8 (CXCL8) is also decreased by E2 in LPS-challenged monocytes, providing evidence of a direct correlation between ER $\alpha$ expression levels and suppression of LPS-induced IL-8 secretion [78].

E2 can significantly influence CD16 expression, a receptor mediating autoimmune disease symptoms, and alter monocytic cytokine release after CD16 receptor activation. E2 reduces CD16 expression and decreases TNF- $\alpha$ and IL-1 $\beta$ release after CD16 stimulation [79]. Kramer et al. reported that CD16 expression can be altered by ER activity and that $\mathrm{ER} \alpha$ can associate with a region in the CD16 promoter involved in transcript production [80]. ER $\beta$ agonist treatment also reduces CD16 expression in macrophages [80] and attenuates the decrease in macrophage IL- 6 and TNF- $\alpha$ production by splenic macrophages after trauma hemorrhage with no effect on the activation of MAPKs and NF- $\mathrm{kB}$ [81]. Xing et al. showed the ability of selective ER $\beta$ activation to inhibit expression of inflammatory mediators [82]. The main effects of E2 on monocyte-macrophages and endothelial cells are depicted in Figure 1.

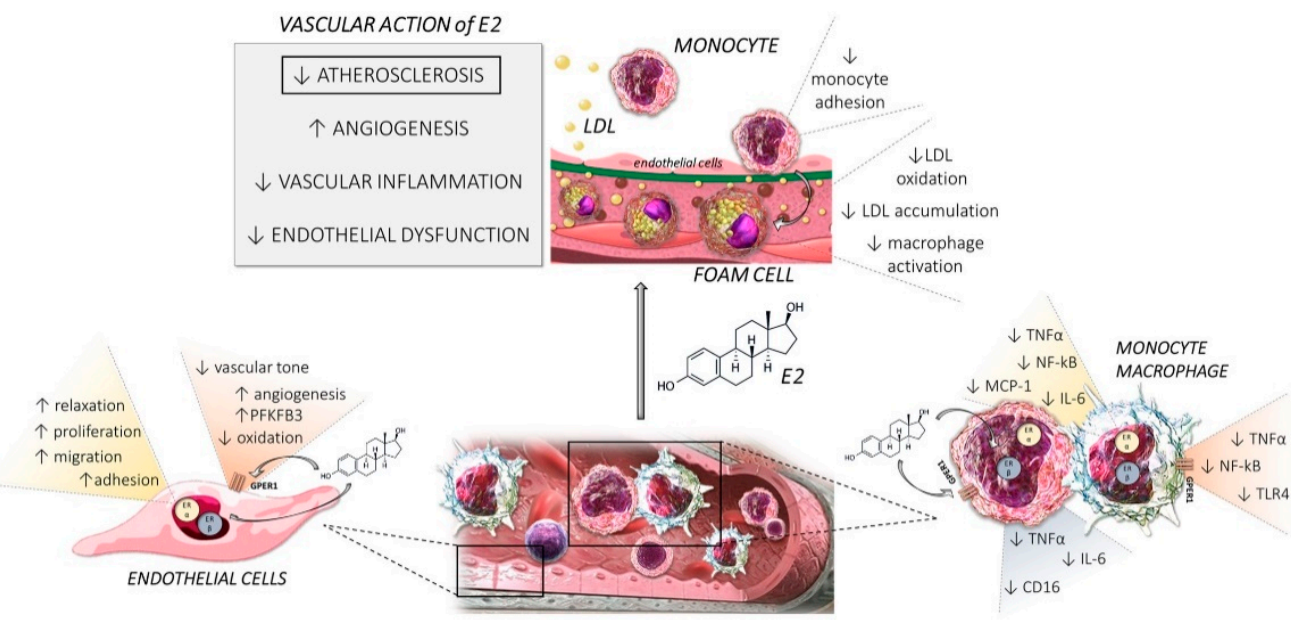

Figure 1. Estrogen/ER pathways induce protective effects in the vessel wall with specific actions on endothelial cells and monocytes/macrophages through various pathways. E2 attenuates inflammation by regulating the induction of chemokines and cytokines at the vascular immune interface that are mediated largely by ER $\alpha$ activation. The interaction between endothelial cells and monocytes/macrophages is relevant in multiple disease settings such as atherosclerosis.

Another major pathway of estrogen regulation of the monocyte-macrophage system is stimulation of production of members of the immunosuppressive transforming growth factor (TGF)- $\beta$ family [50]. Functional effects of the endocrine disruptor bisphenol $\mathrm{A}$ in inducing TNF- $\alpha$ and IL- 6 production, and inhibiting TGF- $\beta$ and IL-10 production via $\mathrm{ER} \alpha / \mathrm{ER} \beta / \mathrm{ERK} / \mathrm{NF}-\mathrm{KB}$ signaling have been reported in human THP-1 macrophages [83]. 
Using a transcriptomic approach, Pepe et al. [84] obtained a comprehensive list of genes that are differentially expressed in peritoneal macrophages in response to physiological levels of E2 injected in intact female mice. They reported that E2 promotes an anti-inflammatory and pro-resolving macrophage phenotype, which converges on the induction of genes related to macrophage alternative activation and on IL-10 expression in vivo [84].

\subsection{Estrogens: Regulators of Macrophage Immunophenotypes}

Macrophages can be stimulated to distinct functional phenotypes: M1 (classically activated) macrophages, M2 (alternatively activated) macrophages and tumor-associated macrophages based on surface markers and cytokine profiles. M1 and M2, however, represent the two extremes in a much more complex phenotype series [85]. There is evidence for an age-relationship of estrogen-macrophage polarization, since cord mononuclear cells respond and post-menopausal monocytes do not [86-88]. In this regard, E2 (and progesterone) impair the response of human cord blood mononuclear cells exposed to microbial products, suggesting that maternal hormones regulate neonatal immune responses. Newborn monocytes are more sensitive to the effects of E2 and progesterone than adult peripheral blood mononuclear cells and monocytes [89].

Much earlier on in life, monocytes contribute to atherosclerotic disease by abnormally trafficking to the vessel wall. By the time menopause arrives, atherosclerosis may be already established. There is an acceleration of atherosclerosis post-menopause and, in part, this is secondary to adverse changes in the serum lipid profile with an increase in LDL-C and decrease in HDL-C. Gene expression changes have been reported comparing the whole heart gene expression profile for aged rats with and without estrogen replacement or with late estrogen replacement, which induced paradoxically a pro-inflammatory set of gene changes [90]. This is consistent with the notion that menopausal hormone therapy may be beneficial for the prevention of cardiovascular disease in post-menopausal women when started less than 10 years but not more than 10 years after the menopause, according to a rigorous Cochrane meta-analysis [91]. We have reported that E2 treatment in vitro prevents LPS-IFN $\gamma$-induced downregulation of alternative activation markers and cytokine production [17]. There is a differential response of post-menopausal versus pre-menopausal macrophages with a blunted response to M2 stimuli in the latter, suggesting that this affects the post-menopausal woman's cardiovascular risk profile.

Macrophage activation is also functionally relevant in tissues other than the vascular wall. Macrophages cause activation of several intracellular pathways in breast cancer cells of which c-Src, protein kinase $C$ and MAPK are essential for loss of ER $\alpha$ expression [92]. Thus, it is possible that one subtype of estrogen receptor (GPER) could actually downregulate the other type (ER $\alpha$ ). Activation of MAPK by GPER (which can cause loss of ER $\alpha$ ) can be described as a feedback inhibition loop for estrogen activation of macrophages and monocytes, and could regulate the balance between M1 and M2 macrophage development. Agents that interfere with ER signaling such as the endocrine disruptor bisphenol A upregulate M1 type responses in the liver of wild-type mice [93].

Further research studies are needed to unravel relevant signaling cascades leading to macrophage polarization and the role of estrogen and other second messengers in it.

\section{A Possible Role for Estrogens in Constraining Myelopoiesis and Cardiovascular Risk}

Hematopoietic stem cells (HSCs) are pluripotent stem cells that produce mature blood cells throughout life, nested in a specialized microenvironment in the adult bone marrow defined "niche" [94]. The niche is as important as the stem cells themselves in regulating their self-renewal and differentiation [95]. ER $\alpha$ is expressed both in osteoblasts, which are a component of the niche, and in different subset of hematopoietic progenitors, even though they lack the expression of $\mathrm{ER} \beta[96,97]$. ER $\alpha$ is dispensable for steady-state hematopoiesis [97], but data support the idea that E2 could instruct the differentiation of HSC. Indeed, E2 regulates HSCs self-renewal during pregnancy [97] and improves hematopoietic recovery and regeneration after transplantation and irradiation [97]. Dia- 
betes is associated with a myeloid-skewed differentiation of bone marrow HSCs, termed myelopoiesis [98], which is linked to profound alteration of the homeostasis of the bone marrow [99]. Myelopoiesis is driven by the activation of common myeloid progenitors by neutrophils-released S100A8/9 or macrophage-derived IL-1 $\beta[98,100]$. The increased amount of pro-inflammatory monocytes and neutrophils released by the bone marrow fuels the progression of atherosclerosis [98] and ultimately contributes to low-grade inflammation and cardiovascular risk. Neutrophils-to-lymphocyte ratio is a marker of systemic inflammation and myelopoiesis, and has been found to be a strong predictor of mortality and cardiovascular risk, while being increased in the elderly and in males [101]. Therefore, it is intriguing to speculate that the effects of estrogens on HSCs might also impinge on restraining the onset of myelopoiesis to explain the protective effects on the cardiovascular system. Some early reports, indeed, showed that E2 reduces myeloid differentiation of HSCs [102-104] and described its role in B lymphocyte development [105]. On the other hand, E2 could directly stimulate myeloid differentiation of HSCs in vitro [106]. As mentioned above, HSCs are entangled in specialized niches that supply metabolic support and differentiation stimuli [94]. E2 is known to modulate bone turnover by affecting osteoblasts and osteoclasts, but its effects on these cells as components of the hematopoietic endosteal niche are unknown. Similarly, endothelial cells are essential in regulating HSCs in the perivascular niche [94], but the possible effects of E2 on bone marrow endothelial cells are still unknown. Indeed, E2 can modulate endothelial cell metabolism through GPER $[45,46]$ and this effect could be exploited to modulate the endothelial cell-HSC cross-talk [107], restrain myelopoiesis and ultimately improve cardiovascular health.

\section{Intricacies of ER Pharmacological Modulation}

As noted in Section 3 above, the traditional ERs (ER $\alpha$ and ER $\beta$ ) are predominantly nuclear-localized proteins, and classically mediate their effects as transcription factors [108]. GPER is a 7-transmembrane GPCR that activates multiple cellular pathways including calcium mobilization, ERK and PI3K via transactivation of the EGF-R [109]. As E2 binds and activates all three ERs (ER $\alpha, E R \beta$ and GPER), selective ligands (agonists and antagonists) are needed to unravel and exploit the functional roles of the individual receptors, particularly GPER [110]. However, diverse ER ligands including phytoestrogens (e.g., genistein), xenoestrogens (e.g., bisphenol A), the "ER $\alpha$-selective" PPT and therapeutic anti-estrogens (e.g., tamoxifen, fulvestrant, raloxifene) act as GPER agonists [111]. Selective estrogen receptor modulators (SERMs) such as tamoxifen and raloxifene provide some degree of tissue selectivity. These agents have been reported to affect the monocyte-macrophage system [50]: for example, raloxifene prevents LDL oxidation and the formation of tyrosyl radicals by myeloperoxidase [112], as well as caspase-3 dependent apoptosis induced by TNF- $\alpha$ in carotid artery endothelial cells [113]. More recently, bazedoxifene has been reported to protect HUVECs from TNF- $\alpha$-induced inflammatory damage by targeting CD40 [114]. However, currently used SERMs do not display remarkable ER subtypespecificity. Thus, none of currently used endogenous or synthetic ER-targeting agents affords ER subtype selectivity.

We viewed the development of ER subtype-selective therapeutic agents, rather than experimental tools, as an unmet pharmacological need already 15 years ago [115]. Later on, we reported that systemic treatment with the ER $\alpha$ agonist propylpyrazoletriol (PPT) provides cardiovascular protection without undesired ER $\alpha$-mediated uterine activation in rodents [116], but a contribution of GPER to PPT effects cannot be ruled out. It is encouraging that a GPER-selective agonist is poised to start clinical development following successful preclinical testing [117]. Another pharmacological challenge in the ER field is the development of agents that uncouple nuclear and membrane ER $\alpha$ activation. Estetrol (E4) has shown such a pattern [118]: this agent is less potent than E2 and shows some tissue selectivity as it induces limited effects on the liver [119]. E4 is under clinical development for a few indications including contraception and breast cancer $[120,121]$. 
Adding further complexity to the field, nonestrogenic ligands are known to modulate ER activity. Several oxysterols including 27-hydroxycholesterol (27HC) not only activate LXR but also display estrogenic activity [122]. Female murine bone marrow-derived macrophages (BMDMs) show higher ER $\alpha$ expression with respect to male BMDMs. Because $\mathrm{ER} \alpha$ and ER $\beta$ target genes differ substantially, the binding of ligands (such as 27HC) to different ER subtypes may impact the fate of the inflammatory signaling [123]. The inflammatory effects of $27 \mathrm{HC}$ in murine BMDMs are sex-opposed only in the presence of E2, indicating a key role for estrogen in the 27HC-induced effect on inflammation [123]. This observation is in line with previous findings of Umetani et al. [124], who linked 27HC to estrogen by identifying 27HC as the first endogenous SERM. Moreover, the angiotensin $\mathrm{AT}_{1}$ receptor antagonist olmesartan suppresses ischemic brain damage, exaggerated in estrogen-deficient rats, at least in part via upregulated expression and phosphorylation of $\mathrm{ER} \alpha$, as well as upregulation of anti-apoptotic genes and of ACE2, resulting in attenuated activation of the renin-angiotensin system after ischemia [125]. These molecular effects occurred in an E2-independent manner and were blocked by fulvestrant, which acts both as a selective ER degrader and as a GPER agonist. Whether off-target ER pathways contribute to olmesartan therapeutic effects in humans remains to be determined.

\section{Conclusions}

Declining estrogen levels are associated with a variety of disorders such as osteoporosis, neuroinflammatory diseases, vascular wall degeneration, cardiovascular diseases and increase the risk of atherosclerosis. Preclinical and clinical evidence suggests that estrogenic agents interfere with early events in atherogenesis taking place at the vascular immune interface. Here modified lipoproteins trigger endothelial dysfunction as well as the accumulation of cholesterol and the production of inflammatory mediators and cytokines by monocyte-derived macrophages. While pharmacological intervention at this site would be instrumental to prevent atherosclerosis progression, current estrogenic agents lack ER subtype-, cell type- and, at least in part, tissue selectivity, leading to systemic undesired effects. Thus, the development of "smart" estrogenic agents targeting the vascular immune interface would provide a novel treatment solution to reduce cardiovascular risk in women.

Author Contributions: A.D., C.B. (Chiara Baggio), C.B. (Carlotta Boscaro), M.A. and A.C. have contributed substantially to the conception, design and writing of this article. All authors have read and agreed to the published version of the manuscript.

Funding: The APC was funded by the MSCA Seal of Excellence@UNIPD 2019 grant to A.D. and A.C. Institutional Review Board Statement: Not applicable.

Informed Consent Statement: Not applicable.

Data Availability Statement: Not applicable.

Conflicts of Interest: The authors declare no conflict of interest. The funder had no role in the writing of the manuscript.

\section{References}

1. Vanhoutte, P.M.; Shimokawa, H.; Feletou, M.; Tang, E.H. Endothelial dysfunction and vascular disease-A 30th anniversary update. Acta Physiol. 2017, 219, 22-96.

2. Schnitzler, J.G.; Dallinga-Thie, G.M.; Kroon, J. The role of (modified) lipoproteins in vascular function: A duet between monocytes and the endothelium. Curr. Med. Chem. 2019, 26, 1594-1609. [CrossRef] [PubMed]

3. Libby, P.; Buring, J.E.; Badimon, L.; Hansson, G.K.; Deanfield, J.; Bittencourt, M.S.; Tokgözoğlu, L.; Lewis, E.F. Atherosclerosis. Nat. Rev. Dis. Primers 2019, 5, 56. [CrossRef] [PubMed]

4. Hansson, G.K. Inflammation, atherosclerosis, and coronary artery disease. N. Engl. J. Med. 2005, 352, 1685-1695. [CrossRef] [PubMed]

5. Moore, K.J.; Sheedy, F.J.; Fisher, E.A. Macrophages in atherosclerosis: A dynamic balance. Nat. Rev. Immunol. 2013, 13, 709-721. [CrossRef] [PubMed]

6. Ait-Oufella, H.; Taleb, S.; Mallat, Z.; Tedgui, A. Recent advances on the role of cytokines in atherosclerosis. Arterioscler. Thromb. Vasc. Biol. 2011, 31, 969-979. [CrossRef] [PubMed] 
7. Wong, K.L.; Tai, J.J.; Wong, W.C.; Han, H.; Sem, X.; Yeap, W.H.; Kourilsky, P.; Wong, S.C. Gene expression profiling reveals the defining features of the classical, intermediate, and nonclassical human monocyte subsets. Blood 2011, 118, e16-e31. [CrossRef]

8. Cignarella, A.; Tedesco, S.; Cappellari, R.; Fadini, G.P. The continuum of monocyte phenotypes: Experimental evidence and prognostic utility in assessing cardiovascular risk. J. Leukoc. Biol. 2018, 103, 1021-1028. [CrossRef]

9. Yvan-Charvet, L.; Bonacina, F.; Guinamard, R.R.; Norata, G.D. Immunometabolic function of cholesterol in cardiovascular disease and beyond. Cardiovasc. Res. 2019, 115, 1393-1407. [CrossRef]

10. Knowlton, A.A.; Lee, A.R. Estrogen and the cardiovascular system. Pharmacol. Ther. 2012, 135, 54-70.

11. Xing, D.; Nozell, S.; Chen, Y.F.; Hage, F.; Oparil, S. Estrogen and mechanisms of vascular protection. Arterioscler. Thromb. Vasc. Biol. 2009, 29, 289-295. [CrossRef] [PubMed]

12. Clarkson, T.B. Estrogen effects on arteries vary with stage of reproductive life and extent of subclinical atherosclerosis progression. Menopause 2018, 25, 1262-1274. [CrossRef] [PubMed]

13. Agarwala, A.; Michos, E.D.; Samad, Z.; Ballantyne, C.M.; Virani, S.S. The use of sex-specific factors in the assessment of women's cardiovascular risk. Circulation 2020, 141, 592-599. [CrossRef] [PubMed]

14. Maas, A.H.E.M.; Rosano, G.; Cifkova, R.; Chieffo, A.; van Dijken, D.; Hamoda, H.; Kunadian, V.; Laan, E.; Lambrinoudaki, I.; Maclaran, K.; et al. Cardiovascular health after menopause transition, pregnancy disorders, and other gynaecologic conditions: A consensus document from European cardiologists, gynaecologists, and endocrinologists. Eur. Heart J. 2021, 42, 967-984. [CrossRef]

15. Honold, L.; Nahrendorf, M. Resident and monocyte-derived macrophages in cardiovascular disease. Circ. Res. 2018, 122, 113-127. [CrossRef] [PubMed]

16. Robbins, C.S.; Hilgendorf, I.; Weber, G.F.; Theurl, I.; Iwamoto, Y.; Figueiredo, J.L.; Gorbatov, R.; Sukhova, G.K.; Gerhardt, L.M.; Smyth, D.; et al. Local proliferation dominates lesional macrophage accumulation in atherosclerosis. Nat. Med. 2013, 19, 1166-1172. [CrossRef]

17. Toniolo, A.; Fadini, G.P.; Tedesco, S.; Cappellari, R.; Vegeto, E.; Maggi, A.; Avogaro, A.; Bolego, C.; Cignarella, A. Alternative activation of human macrophages is rescued by estrogen treatment in vitro and impaired by menopausal status. J. Clin. Endocrinol. Metab. 2015, 100, E50-E58. [CrossRef]

18. Menazza, S.; Murphy, E. The expanding complexity of estrogen receptor signaling in the cardiovascular system. Circ. Res. 2016, 118, 994-1007. [CrossRef]

19. Murphy, A.J.; Guyre, P.M.; Wira, C.R.; Pioli, P.A. Estradiol regulates expression of estrogen receptor ER $\alpha 46$ in human macrophages. PLoS ONE 2009, 4, e5539. [CrossRef]

20. Pelekanou, V.; Kampa, M.; Kiagiadaki, F.; Deli, A.; Theodoropoulos, P.; Agrogiannis, G.; Patsouris, E.; Tsapis, A.; Castanas, E.; Notas, G. Estrogen anti-inflammatory activity on human monocytes is mediated through cross-talk between estrogen receptor ER $\alpha 36$ and GPR30/GPER1. J. Leukoc. Biol. 2016, 99, 333-347. [CrossRef]

21. Stygar, D.; Westlund, P.; Eriksson, H.; Sahlin, L. Identification of wild type and variants of oestrogen receptors in polymorphonuclear and mononuclear leucocytes. Clin. Endocrinol. 2006, 64, 74-81. [CrossRef]

22. Prossnitz, E.R.; Barton, M. The G-protein-coupled estrogen receptor GPER in health and disease. Nat. Rev. Endocrinol. 2011, 7, 715-726. [CrossRef] [PubMed]

23. Prossnitz, E.R.; Arterburn, J.B. International Union of Basic and Clinical Pharmacology. XCVII. G protein-coupled estrogen receptor and its pharmacologic modulators. Pharmacol. Rev. 2015, 67, 505-540. [CrossRef] [PubMed]

24. Lindsey, S.H.; Cohen, J.A.; Brosnihan, K.B.; Gallagher, P.E.; Chappell, M.C. Chronic treatment with the G protein-coupled receptor 30 agonist G-1 decreases blood pressure in ovariectomized mRen2.Lewis rats. Endocrinology 2009, 150, 3753-3758. [CrossRef] [PubMed]

25. Tran, Q.K. Reciprocality between estrogen biology and calcium signaling in the cardiovascular system. Front. Endocrinol. 2020, 11, 568203. [CrossRef] [PubMed]

26. Ribas, V.; Nguyen, M.T.; Henstridge, D.C.; Nguyen, A.K.; Beaven, S.W.; Watt, M.J.; Hevener, A.L. Impaired oxidative metabolism and inflammation are associated with insulin resistance in ER $\alpha$-deficient mice. Am. J. Physiol. Endocrinol. Metab. 2010, 298, E304-E319. [CrossRef] [PubMed]

27. Zhu, Y.; Bian, Z.; Lu, P.; Karas, R.H.; Bao, L.; Cox, D.; Hodgin, J.; Shaul, P.W.; Thoren, P.; Smithies, O.; et al. Abnormal vascular function and hypertension in mice deficient in estrogen receptor beta. Science 2002, 295, 505-508. [CrossRef]

28. Meyer, M.R.; Amann, K.; Field, A.S.; Hu, C.; Hathaway, H.J.; Kanagy, N.L.; Walker, M.K.; Barton, M.; Prossnitz, E.R. Deletion of G protein-coupled estrogen receptor increases endothelial vasoconstriction. Hypertension 2012, 59, 507-512. [CrossRef]

29. Bolego, C.; Cignarella, A.; Sanvito, P.; Pelosi, V.; Pellegatta, F.; Puglisi, L.; Pinna, C. The acute estrogenic dilation of rat aorta is mediated solely by selective estrogen receptor- $\alpha$ agonists and is abolished by estrogen deprivation. J. Pharmacol. Exp. Ther. 2005, 313, 1203-1208. [CrossRef]

30. Meyer, M.R.; Fredette, N.C.; Barton, M.; Prossnitz, E.R. Endothelin-1 but not angiotensin II contributes to functional aging in murine carotid arteries. Life Sci. 2014, 118, 213-218. [CrossRef]

31. Tran, Q.K.; Firkins, R.; Giles, J.; Francis, S.; Matnishian, V.; Tran, P.; VerMeer, M.; Jasurda, J.; Burgard, M.A.; Gebert-Oberle, B. Estrogen enhances linkage in the vascular endothelial calmodulin network via a feedforward mechanism at the $G$ protein-coupled estrogen receptor 1. J. Biol. Chem. 2016, 291, 10805-10823. [CrossRef] 
32. Boscaro, C.; Trenti, A.; Baggio, C.; Scapin, C.; Trevisi, L.; Cignarella, A.; Bolego, C. Sex differences in the pro-angiogenic response of human endothelial cells: Focus on PFKFB3 and FAK activation. Front. Pharmacol. 2020, 11, 587221. [CrossRef]

33. Mudrovcic, N.; Arefin, S.; Van Craenenbroeck, A.H.; Kublickiene, K. Endothelial maintenance in health and disease: Importance of sex differences. Pharmacol. Res. 2017, 119, 48-60. [CrossRef]

34. Morales, D.E.; McGowan, K.A.; Grant, D.S.; Maheshwari, S.; Bhartiya, D.; Cid, M.C.; Kleinman, H.K.; Schnaper, H.W. Estrogen promotes angiogenic activity in human umbilical vein endothelial cells in vitro and in a murine model. Circulation 1995, 91, 755-763. [CrossRef] [PubMed]

35. Krasinski, K.; Spyridopoulos, I.; Asahara, T.; van der Zee, R.; Isner, J.M.; Losordo, D.W. Estradiol accelerates functional endothelial recovery after arterial injury. Circulation 1997, 95, 1768-1772. [CrossRef]

36. Concina, P.; Sordello, S.; Barbacanne, M.A.; Elhage, R.; Pieraggi, M.T.; Fournial, G.; Plouet, J.; Bayard, F.; Arnal, J.F. The mitogenic effect of $17 \beta$-estradiol on in vitro endothelial cell proliferation and on in vivo reendothelialization are both dependent on vascular endothelial growth factor. J. Vasc. Res. 2000, 37, 202-208. [CrossRef] [PubMed]

37. Alvarez, R.J.; Gips, S.J.; Moldovan, N.; Wilhide, C.C.; Milliken, E.E.; Hoang, A.T.; Hruban, R.H.; Silverman, H.S.; Dang, C.V.; Goldschmidt-Clermont, P.J. 17ß-estradiol inhibits apoptosis of endothelial cells. Biochem. Biophys. Res. Commun. 1997, 237, 372-381. [CrossRef]

38. Spyridopoulos, I.; Sullivan, A.B.; Kearney, M.; Isner, J.M.; Losordo, D.W. Estrogen-receptor-mediated inhibition of human endothelial cell apoptosis-Estradiol as a survival factor. Circulation 1997, 95, 1505-1514. [CrossRef] [PubMed]

39. Simoncini, T.; Scorticati, C.; Mannella, P.; Fadiel, A.; Giretti, M.S.; Fu, X.D.; Baldacci, C.; Garibaldi, S.; Caruso, A.; Fornari, L.; et al. Estrogen receptor $\alpha$ interacts with $G \alpha_{13}$ to drive actin remodeling and endothelial cell migration via the RhoA/Rho kinase/moesin pathway. Mol. Endocrinol. 2006, 20, 1756-1771. [CrossRef]

40. Sanchez, A.M.; Flamini, M.I.; Zullino, S.; Gopal, S.; Genazzani, A.R.; Simoncini, T. Estrogen receptor- $\alpha$ promotes endothelial cell motility through focal adhesion kinase. Mol. Hum. Reprod. 2011, 17, 219-226. [CrossRef]

41. Johns, A.; Freay, A.D.; Fraser, W.; Korach, K.S.; Rubanyi, G.M. Disruption of estrogen receptor gene prevents $17 \beta$ estradiol-induced angiogenesis in transgenic mice. Endocrinology 1996, 137, 4511-4513. [CrossRef]

42. Losordo, D.W.; Isner, J.M. Estrogen and angiogenesis: A review. Arterioscler. Thromb. Vasc. Biol. 2001, 21, 6-12. [CrossRef]

43. Missiaen, R.; Morales-Rodriguez, F.; Eelen, G.; Carmeliet, P. Targeting endothelial metabolism for anti-angiogenesis therapy: A pharmacological perspective. Vascul. Pharmacol. 2017, 90, 8-18. [CrossRef]

44. Mauvais-Jarvis, F.; Clegg, D.J.; Hevener, A.L. The role of estrogens in control of energy balance and glucose homeostasis. Endocr. Rev. 2013, 34, 309-338. [CrossRef]

45. Trenti, A.; Tedesco, S.; Boscaro, C.; Ferri, N.; Cignarella, A.; Trevisi, L.; Bolego, C. The glycolytic enzyme PFKFB3 is involved in estrogen-mediated angiogenesis via GPER1. J. Pharmacol. Exp. Ther. 2017, 361, 398-407. [CrossRef] [PubMed]

46. Boscaro, C.; Carotti, M.; Albiero, M.; Trenti, A.; Fadini, G.P.; Trevisi, L.; Sandonà, D.; Cignarella, A.; Bolego, C. Non-genomic mechanisms in the estrogen regulation of glycolytic protein levels in endothelial cells. FASEB J. 2020, 34, 12768-12784. [CrossRef] [PubMed]

47. Neves, K.B.; Montezano, A.C.; Lang, N.N.; Touyz, R.M. Vascular toxicity associated with anti-angiogenic drugs. Clin. Sci. 2020, 134, 2503-2520. [CrossRef] [PubMed]

48. Kramer, P.R.; Wray, S. 17- $\beta$-Estradiol regulates expression of genes that function in macrophage activation and cholesterol homeostasis. J. Steroid Biochem. Mol. Biol. 2002, 81, 203-216. [CrossRef]

49. Bolego, C.; Cignarella, A.; Staels, B.; Chinetti-Gbaguidi, G. Macrophage function and polarization in cardiovascular disease: A role of estrogen signaling? Arterioscler. Thromb. Vasc. Biol. 2013, 33, 1127-1134. [CrossRef]

50. Härkönen, P.L.; Väänänen, H.K. Monocyte-macrophage system as a target for estrogen and selective estrogen receptor modulators. Annu. N. Y. Acad. Sci. 2006, 1089, 218-227. [CrossRef] [PubMed]

51. Campesi, I.; Marino, M.; Montella, A.; Pais, S.; Franconi, F. Sex differences in estrogen receptor $\alpha$ and $\beta$ levels and activation status in LPS-stimulated human macrophages. J. Cell Physiol. 2017, 232, 340-345. [CrossRef] [PubMed]

52. Frazier-Jessen, M.R.; Kovacs, E.J. Estrogen modulation of JE/monocyte chemoattractant protein-1 mRNA expression in murine macrophages. J. Immunol. 1995, 154, 1838-1845.

53. Friedrich, E.B.; Clever, Y.P.; Wassmann, S.; Hess, C.; Nickenig, G. 17 $\beta$-estradiol inhibits monocyte adhesion via down-regulation of Rac1 GTPase. J. Mol. Cell Cardiol. 2006, 40, 87-95. [CrossRef] [PubMed]

54. Okada, M.; Suzuki, A.; Mizuno, K.; Asada, Y.; Ino, Y.; Kuwayama, T.; Tamakoshi, K.; Mizutani, S.; Tomoda, Y. Effects of $17 \beta$-estradiol and progesterone on migration of human monocytic THP-1 cells stimulated by minimally oxidized low-density lipoprotein in vitro. Cardiovasc. Res. 1997, 34, 529-535. [CrossRef]

55. Huber, L.A.; Scheffler, E.; Poll, T.; Ziegler, R.; Dresel, H.A. 17 beta-estradiol inhibits LDL oxidation and cholesteryl ester formation in cultured macrophages. Free Radic. Res. Commun. 1990, 8, 167-173. [CrossRef]

56. Ribas, V.; Drew, B.G.; Le, J.A.; Soleymani, T.; Daraei, P.; Sitz, D.; Mohammad, L.; Henstridge, D.C.; Febbraio, M.A.; Hewitt, S.C.; et al. Myeloid-specific estrogen receptor $\alpha$ deficiency impairs metabolic homeostasis and accelerates atherosclerotic lesion development. Proc. Natl. Acad. Sci. USA 2011, 108, 16457-16462. [CrossRef]

57. Hodgin, J.B.; Krege, J.H.; Reddick, R.L.; Korach, K.S.; Smithies, O.; Maeda, N. Estrogen receptor $\alpha$ is a major mediator of 17ß-estradiol's atheroprotective effects on lesion size in Apoe ${ }^{-/-}$mice. J. Clin. Investig. 2001, 107, 333-340. [CrossRef] 
58. Cignarella, A.; Engel, T.; von Eckardstein, A.; Kratz, M.; Lorkowski, S.; Lueken, A.; Assmann, G.; Cullen, P. Pharmacological regulation of cholesterol efflux in human monocyte-derived macrophages in the absence of exogenous cholesterol acceptors. Atherosclerosis 2005, 179, 229-236. [CrossRef]

59. Shibata, N.; Glass, C.K. Regulation of macrophage function in inflammation and atherosclerosis. J. Lipid Res. 2009, 50, S277-S281. [CrossRef]

60. Shahoei, S.H.; Nelson, E.R. Nuclear receptors, cholesterol homeostasis and the immune system. J. Steroid Biochem. Mol. Biol. 2019, 191, 105364. [CrossRef]

61. Unanue, E.R. Cooperation between mononuclear phagocytes and lymphocytes in immunity. N. Engl. J. Med. 1980, 303, 977-985. [CrossRef]

62. Burger, D.; Dayer, J.M. Cytokines, acute-phase proteins, and hormones-IL-1 and TNF- $\alpha$ production in contact-mediated activation of monocytes by T lymphocytes. Annu. N. Y. Acad. Sci. 2002, 966, 464-473. [CrossRef]

63. Mohammad, I.; Starskaia, I.; Nagy, T.; Guo, J.; Yatkin, E.; Väänänen, K.; Watford, W.T.; Chen, Z. Estrogen receptor $\alpha$ contributes to T cell-mediated autoimmune inflammation by promoting T cell activation and proliferation. Sci. Signal. 2018, 11, eaap9415. [CrossRef]

64. Benedek, G.; Zhang, J.; Nguyen, H.; Kent, G.; Seifert, H.; Vandenbark, A.A.; Offner, H. Novel feedback loop between M2 macrophages/microglia and regulatory B cells in estrogen-protected EAE mice. J. Neuroimmunol. 2017, 305, 59-67. [CrossRef]

65. Bongen, E.; Lucian, H.; Khatri, A.; Fragiadakis, G.K.; Bjornson, Z.B.; Nolan, G.P.; Utz, P.J.; Khatri, P. Sex differences in the blood transcriptome identify robust changes in immune cell proportions with aging and influenza infection. Cell Rep. 2019, 29, 1961-1973.e4. [CrossRef] [PubMed]

66. Shepherd, R.; Cheung, A.S.; Pang, K.; Saffery, R.; Novakovic, B. Sexual dimorphism in innate immunity: The role of sex hormones and epigenetics. Front. Immunol. 2021, 11, 604000. [CrossRef] [PubMed]

67. Ulrich, C.M.; Toriola, A.T.; Koepl, L.M.; Sandifer, T.; Poole, E.M.; Duggan, C.; McTiernan, A.; Issa, J.P. Metabolic, hormonal and immunological associations with global DNA methylation among postmenopausal women. Epigenetics 2012, 7, 1020-1028. [CrossRef] [PubMed]

68. Sharma, G.; Prossnitz, E.R. Targeting the G protein-coupled estrogen receptor (GPER) in obesity and diabetes. Endocr. Metab. Sci. 2021, 2, 100080. [CrossRef]

69. Calippe, B.; Douin-Echinard, V.; Delpy, L.; Laffargue, M.; Lélu, K.; Krust, A.; Pipy, B.; Bayard, F.; Arnal, J.F.; Guéry, J.C.; et al. $17 \beta$-estradiol promotes TLR4-triggered proinflammatory mediator production through direct estrogen receptor $\alpha$ signaling in macrophages in vivo. J. Immunol. 2010, 185, 1169-1176. [CrossRef]

70. Campbell, L.; Emmerson, E.; Williams, H.; Saville, C.R.; Krust, A.; Chambon, P.; Mace, K.A.; Hardman, M.J. Estrogen receptoralpha promotes alternative macrophage activation during cutaneous repair. J. Investig. Dermatol. 2014, 134, 2447-2457. [CrossRef] [PubMed]

71. Trenti, A.; Tedesco, S.; Boscaro, C.; Trevisi, L.; Bolego, C.; Cignarella, A. Estrogen, angiogenesis, immunity and cell metabolism: Solving the puzzle. Int. J. Mol. Sci. 2018, 19, 859. [CrossRef]

72. Straub, R.H. The complex role of estrogens in inflammation. Endocr. Rev. 2007, 28, 521-574. [CrossRef]

73. Miller, A.P.; Feng, W.; Xing, D.; Weathington, N.M.; Blalock, J.E.; Chen, Y.F.; Oparil, S. Estrogen modulates inflammatory mediator expression and neutrophil chemotaxis in injured arteries. Circulation 2004, 110, 1664-1669. [CrossRef]

74. Murphy, A.J.; Guyre, P.M.; Pioli, P.A. Estradiol suppresses NF-kB activation through coordinated regulation of let-7a and miR-125b in primary human macrophages. J. Immunol. 2010, 184, 5029-5037. [CrossRef] [PubMed]

75. Soucy, G.; Boivin, G.; Labrie, F.; Rivest, S. Estradiol is required for a proper immune response to bacterial and viral pathogens in the female brain. J. Immunol. 2005, 174, 6391-6398. [CrossRef] [PubMed]

76. Ghisletti, S.; Meda, C.; Maggi, A.; Vegeto, E. 17 $\beta$-estradiol inhibits inflammatory gene expression by controlling NF- $\mathrm{B}$ B intracellular localization. Mol. Cell Biol. 2005, 25, 2957-2968. [CrossRef] [PubMed]

77. Lambert, K.C.; Curran, E.M.; Judy, B.M.; Lubahn, D.B.; Estes, D.M. Estrogen receptor- $\alpha$ deficiency promotes increased TNF- $\alpha$ secretion and bacterial killing by murine macrophages in response to microbial stimuli in vitro. J. Leukoc. Biol. 2004, 75, 1166-1172 [CrossRef]

78. Pioli, P.A.; Jensen, A.L.; Weaver, L.K.; Amiel, E.; Shen, Z.; Shen, L.; Wira, C.R.; Guyre, P.M. Estradiol attenuates lipopolysaccharideinduced CXC chemokine ligand 8 production by human peripheral blood monocytes. J. Immunol. 2007, 179, 6284-6290. [CrossRef]

79. Kramer, P.R.; Kramer, S.F.; Guan, G. 17 $\beta$-Estradiol regulates cytokine release through modulation of CD16 expression in monocytes and monocyte-derived macrophages. Arthritis Rheum. 2004, 50, 1967-1975. [CrossRef] [PubMed]

80. Kramer, P.R.; Winger, V.; Kramer, S.F. 17 $\beta$-Estradiol utilizes the estrogen receptor to regulate CD16 expression in monocytes. Mol. Cell Endocrinol. 2007, 279, 16-25. [CrossRef]

81. Suzuki, T.; Shimizu, T.; Yu, H.P.; Hsieh, Y.C.; Choudhry, M.A.; Bland, K.I.; Chaudry, I.H. Estrogen receptor- $\alpha$ predominantly mediates the salutary effects of $17 \beta$-estradiol on splenic macrophages following trauma-hemorrhage. Am. J. Physiol. Cell Physiol. 2007, 293, C978-C984. [CrossRef]

82. Xing, D.; Oparil, S.; Yu, H.; Gong, K.; Feng, W.; Black, J.; Chen, Y.F.; Nozell, S. Estrogen modulates NFkB signaling by enhancing I $\mathrm{K} \mathrm{\alpha} \alpha$ levels and blocking $\mathrm{p} 65$ binding at the promoters of inflammatory genes via estrogen receptor- $\beta$. PLoS ONE 2012, 7, e36890. [CrossRef] 
83. Liu, Y.; Mei, C.; Liu, H.; Wang, H.; Zeng, G.; Lin, J.; Xu, M. Modulation of cytokine expression in human macrophages by endocrine-disrupting chemical bisphenol-A. Biochem. Biophys. Res. Commun. 2014, 451, 592-598. [CrossRef]

84. Pepe, G.; Braga, D.; Renzi, T.A.; Villa, A.; Bolego, C.; D’Avila, F.; Barlassina, C.; Maggi, A.; Locati, M.; Vegeto, E. Self-renewal and phenotypic conversion are the main physiological responses of macrophages to the endogenous estrogen surge. Sci. Rep. 2017, 7, 44270. [CrossRef] [PubMed]

85. Murray, P.J. Macrophage polarization. Annu. Rev. Physiol. 2017, 79, 541-566. [CrossRef] [PubMed]

86. Bowling, M.R.; Xing, D.; Kapadia, A.; Chen, Y.F.; Szalai, A.J.; Oparil, S.; Hage, F.G. Estrogen effects on vascular inflammation are age dependent: Role of estrogen receptors. Arterioscler. Thromb. Vasc. Biol. 2014, 34, 1477-1485. [CrossRef] [PubMed]

87. Stopinska-Gluszak, U.; Waligora, J.; Grzela, T.; Gluszak, M.; Jozwiak, J.; Radomski, D.; Roszkowski, P.I.; Malejczyk, J. Effect of estrogen/progesterone hormone replacement therapy on natural killer cell cytotoxicity and immunoregulatory cytokine release by peripheral blood mononuclear cells of postmenopausal women. J. Reprod. Immunol. 2006, 69, 65-75. [CrossRef]

88. Corcoran, M.P.; Meydani, M.; Lichtenstein, A.H.; Schaefer, E.J.; Dillard, A.; Lamon-Fava, S. Sex hormone modulation of proinflammatory cytokine and C-reactive protein expression in macrophages from older men and postmenopausal women. $J$. Endocrinol. 2010, 206, 217-224. [CrossRef] [PubMed]

89. Giannoni, E.; Guignard, L.; Knaup Reymond, M.; Perreau, M.; Roth-Kleiner, M.; Calandra, T.; Roger, T. Estradiol and progesterone strongly inhibit the innate immune response of mononuclear cells in newborns. Infect. Immun. 2011, 79, 2690-2698. [CrossRef]

90. Pechenino, A.S.; Lin, L.; Mbai, F.N.; Lee, A.R.; He, X.M.; Stallone, J.N.; Knowlton, A.A. Impact of aging vs. estrogen loss on cardiac gene expression: Estrogen replacement and inflammation. Physiol. Genom. 2011, 43, 1065-1073. [CrossRef]

91. Boardman, H.M.; Hartley, L.; Eisinga, A.; Main, C.; Roqué i Figuls, M.; Bonfill Cosp, X.; Gabriel Sanchez, R.; Knight, B. Hormone therapy for preventing cardiovascular disease in post-menopausal women. Cochrane Database Syst. Rev. 2015, 3, CD002229. [CrossRef] [PubMed]

92. Stossi, F.; Madak-Erdoğan, Z.; Katzenellenbogen, B. Macrophage-elicited loss of estrogen receptor- $\alpha$ in breast cancer cells via involvement of MAPK and c-Jun at the ESR1 genomic locus. Oncogene 2012, 31, 1825-1834. [CrossRef] [PubMed]

93. Lv, Q.; Gao, R.; Peng, C.; Yi, J.; Liu, L.; Yang, S.; Li, D.; Hu, J.; Luo, T.; Mei, M.; et al. Bisphenol A promotes hepatic lipid deposition involving Kupffer cells M1 polarization in male mice. J. Endocrinol. 2017, 234, 143-154. [CrossRef] [PubMed]

94. Morrison, S.J.; Scadden, D.T. The bone marrow niche for haematopoietic stem cells. Nature 2014, 505, 327-334. [CrossRef] [PubMed]

95. Xie, T.; Li, L. Stem cells and their niche: An inseparable relationship. Development 2007, 134, 2001-2006. [CrossRef] [PubMed]

96. Sánchez-Aguilera, A.; Arranz, L.; Martín-Pérez, D.; García-García, A.; Stavropoulou, V.; Kubovcakova, L.; Isern, J.; MartínSalamanca, S.; Langa, X.; Skoda, R.C.; et al. Estrogen signaling selectively induces apoptosis of hematopoietic progenitors and myeloid neoplasms without harming steady-state hematopoiesis. Cell Stem Cell 2014, 15, 791-804. [CrossRef]

97. Nakada, D.; Oguro, H.; Levi, B.P.; Ryan, N.; Kitano, A.; Saitoh, Y.; Takeichi, M.; Wendt, G.R.; Morrison, S.J. Oestrogen increases haematopoietic stem-cell self-renewal in females and during pregnancy. Nature 2014, 505, 555-558. [CrossRef]

98. Nagareddy, P.R.; Murphy, A.J.; Stirzaker, R.A.; Hu, Y.; Yu, S.; Miller, R.G.; Ramkhelawon, B.; Distel, E.; Westerterp, M.; Huang, L.S.; et al. Hyperglycemia promotes myelopoiesis and impairs the resolution of atherosclerosis. Cell Metab. 2013, 17, 695-708. [CrossRef]

99. Albiero, M.; Ciciliot, S.; Tedesco, S.; Menegazzo, L.; D’Anna, M.; Scattolini, V.; Cappellari, R.; Zuccolotto, G.; Rosato, A.; Cignarella, A.; et al. Diabetes-associated myelopoiesis drives stem cell mobilopathy through an OSM-p66Shc signaling pathway. Diabetes 2019, 68, 1303-1314. [CrossRef] [PubMed]

100. Nagareddy, P.R.; Kraakman, M.; Masters, S.L.; Stirzaker, R.A.; Gorman, D.J.; Grant, R.W.; Dragoljevic, D.; Hong, E.S.; Abdel-Latif, A.; Smyth, S.S.; et al. Adipose tissue macrophages promote myelopoiesis and monocytosis in obesity. Cell Metab. 2014, 19, 821-835. [CrossRef]

101. Fest, J.; Ruiter, T.R.; Groot Koerkamp, B.; Rizopoulos, D.; Ikram, M.A.; van Eijck, C.H.J.; Stricker, B.H. The neutrophil-tolymphocyte ratio is associated with mortality in the general population: The Rotterdam Study. Eur. J. Epidemiol. 2019, 34, 463-470. [CrossRef]

102. Gaunt, S.D.; Pierce, K.R. Myelopoiesis and marrow adherent cells in estradiol-treated mice. Vet. Pathol. 1985, 22, 403-408. [CrossRef]

103. Gaunt, S.D.; Pierce, K.R. Effects of estradiol on hematopoietic and marrow adherent cells of dogs. Am. J. Vet. Res. 1986, 47, 906-909.

104. Farris, G.M.; Benjamin, S.A. Inhibition of myelopoiesis by conditioned medium from cultured canine thymic cells exposed to estrogen. Am. J. Vet. Res. 1993, 54, 1366-1373. [PubMed]

105. Thurmond, T.S.; Murante, F.G.; Staples, J.E.; Silverstone, A.E.; Korach, K.S.; Gasiewicz, T.A. Role of estrogen receptor $\alpha$ in hematopoietic stem cell development and B lymphocyte maturation in the male mouse. Endocrinology 2000, 141, 2309-2318. [CrossRef]

106. Chapple, R.H.; Hu, T.; Tseng, Y.J.; Liu, L.; Kitano, A.; Luu, V.; Hoegenauer, K.A.; Iwawaki, T.; Li, Q.; Nakada, D. ER $\alpha$ promotes murine hematopoietic regeneration through the Ire $1 \alpha$-mediated unfolded protein response. eLife 2018, 7, e31159. [CrossRef] [PubMed] 
107. Hoyer, F.F.; Zhang, X.; Coppin, E.; Vasamsetti, S.B.; Modugu, G.; Schloss, M.J.; Rohde, D.; McAlpine, C.S.; Iwamoto, Y.; Libby, P.; et al. Bone marrow endothelial cells regulate myelopoiesis in diabetes mellitus. Circulation 2020, 142, 244-258. [CrossRef] [PubMed]

108. Edwards, D.P. Regulation of signal transduction pathways by estrogen and progesterone. Annu. Rev. Physiol. 2005, 67, 335-376. [CrossRef]

109. Revankar, C.M.; Cimino, D.F.; Sklar, L.A.; Arterburn, J.B.; Prossnitz, E.R. A transmembrane intracellular estrogen receptor mediates rapid cell signaling. Science 2005, 307, 1625-1630. [CrossRef] [PubMed]

110. Prossnitz, E.R.; Sklar, L.A.; Oprea, T.I.; Arterburn, J.B. GPR30: A novel therapeutic target in estrogen-related disease. Trends Pharmacol. Sci. 2008, 29, 116-123. [CrossRef]

111. Filardo, E.J.; Quinn, J.A.; Bland, K.I.; Frackelton, A.R., Jr. Estrogen-induced activation of Erk-1 and Erk-2 requires the G proteincoupled receptor homolog, GPR30, and occurs via trans-activation of the epidermal growth factor receptor through release of HB-EGF. Mol. Endocrinol. 2000, 14, 1649-1660. [CrossRef]

112. Zuckerman, S.H.; Bryan, N. Inhibition of LDL oxidation and myeloperoxidase dependent tyrosyl radical formation by the selective estrogen receptor modulator raloxifene (LY139481 HCL). Atherosclerosis 1996, 126, 65-75. [CrossRef]

113. Yu, J.; Eto, M.; Akishita, M.; Okabe, T.; Ouchi, Y. A selective estrogen receptor modulator inhibits TNF- $\alpha$-induced apoptosis by activating ERK1/2 signaling pathway in vascular endothelial cells. Vascul. Pharmacol. 2009, 51, 21-28. [CrossRef] [PubMed]

114. Song, W.; Lv, Y.; Tang, Z.; Nie, F.; Huang, P.; Pei, Q.; Guo, R. Bazedoxifene plays a protective role against inflammatory injury of endothelial cells by targeting CD40. Cardiovasc Ther. 2020, 2020, 1795853. [CrossRef] [PubMed]

115. Bolego, C.; Vegeto, E.; Pinna, C.; Maggi, A.; Cignarella, A. Selective agonists of estrogen receptor isoforms: New perspectives for cardiovascular disease. Arterioscler. Thromb. Vasc. Biol. 2006, 26, 2192-2199. [CrossRef] [PubMed]

116. Bolego, C.; Rossoni, G.; Fadini, G.P.; Vegeto, E.; Pinna, C.; Albiero, M.; Boscaro, E.; Agostini, C.; Avogaro, A.; Gaion, R.M.; et al. Selective estrogen receptor- $\alpha$ agonist provides widespread heart and vascular protection with enhanced endothelial progenitor cell mobilization in the absence of uterotrophic action. FASEB J. 2010, 24, 2262-2272. [CrossRef] [PubMed]

117. Sharma, G.; Hu, C.; Staquicini, D.I.; Brigman, J.L.; Liu, M.; Mauvais-Jarvis, F.; Pasqualini, R.; Arap, W.; Arterburn, J.B.; Hathaway, H.J.; et al. Preclinical efficacy of the GPER-selective agonist G-1 in mouse models of obesity and diabetes. Sci. Transl. Med. 2020, 12. [CrossRef] [PubMed]

118. Abot, A.; Fontaine, C.; Buscato, M.; Solinhac, R.; Flouriot, G.; Fabre, A.; Drougard, A.; Rajan, S.; Laine, M.; Milon, A.; et al. The uterine and vascular actions of estetrol delineate a distinctive profile of estrogen receptor $\alpha$ modulation, uncoupling nuclear and membrane activation. EMBO Mol. Med. 2014, 6, 1328-1346. [CrossRef]

119. Buscato, M.; Davezac, M.; Zahreddine, R.; Adlanmerini, M.; Métivier, R.; Fillet, M.; Cobraiville, G.; Moro, C.; Foidart, J.M.; Lenfant, F.; et al. Estetrol prevents Western diet-induced obesity and atheroma independently of hepatic estrogen receptor $\alpha$. Am. J. Physiol. Endocrinol. Metab. 2021, 320, E19-E29. [CrossRef]

120. Abderrahman, B.; Maximov, P.Y.; Curpan, R.F.; Hanspal, J.S.; Fan, P.; Xiong, R.; Tonetti, D.A.; Thatcher, G.R.J.; Jordan, V.C. Pharmacology and molecular mechanisms of clinically relevant estrogen estetrol and estrogen mimic BMI-135 for the treatment of endocrine-resistant breast cancer. Mol. Pharmacol. 2020, 98, 364-381. [CrossRef]

121. Coelingh Bennink, H.J.; Verhoeven, C.; Zimmerman, Y.; Visser, M.; Foidart, J.M.; Gemzell-Danielsson, K. Clinical effects of the fetal estrogen estetrol in a multiple-rising-dose study in postmenopausal women. Maturitas 2016, 91, 93-100. [CrossRef] [PubMed]

122. Ma, L.; Wang, L.; Nelson, A.T.; Han, C.; He, S.; Henn, M.A.; Menon, K.; Chen, J.J.; Baek, A.E.; Vardanyan, A.; et al. 27Hydroxycholesterol acts on myeloid immune cells to induce $\mathrm{T}$ cell dysfunction, promoting breast cancer progression. Cancer Lett. 2020, 493, 266-283. [CrossRef] [PubMed]

123. Houben, T.; Bitorina, A.V.; Oligschlaeger, Y.; Jeurissen, M.L.; Rensen, S.; Köhler, S.E.; Westerterp, M.; Lütjohann, D.; Theys, J.; Romano, A.; et al. Sex-opposed inflammatory effects of 27-hydroxycholesterol are mediated via differences in estrogen signaling. J. Pathol. 2020, 251, 429-439. [CrossRef] [PubMed]

124. Umetani, M.; Domoto, H.; Gormley, A.K.; Yuhanna, I.S.; Cummins, C.L.; Javitt, N.B.; Korach, K.S.; Shaul, P.W.; Mangelsdorf, D.J. 27-Hydroxycholesterol is an endogenous SERM that inhibits the cardiovascular effects of estrogen. Nat. Med. 2007, 13, 1185-1192. [CrossRef] [PubMed]

125. Shimada, K.; Kitazato, K.T.; Kinouchi, T.; Yagi, K.; Tada, Y.; Satomi, J.; Kageji, T.; Nagahiro, S. Activation of estrogen receptor- $\alpha$ and of angiotensin-converting enzyme 2 suppresses ischemic brain damage in oophorectomized rats. Hypertension 2011, 57, 1161-1166. [CrossRef] 